\author{
Paulina Rosalska \\ Uniwersytet Mikołaja Kopernika w Toruniu \\ Instytut Językoznawstwa
}

ORCID: 0000-0002-0231-5933

\title{
Jednostki języka oparte na ciągu tącznie
}

\begin{abstract}
A b s trakt: W artykule została zawarta analiza sześciu typów kontekstów w języku polskim, w których występuje ciąg łącznie. Jej celem była próba wyodrębnienia jednostek języka, które może on reprezentować lub których może być członem. Wyodrębniono pięć hipotetycznych jednostek języka - dwie o kształcie łącznie, dwie o kształcie łącznie z i jedną wielosegmentową jednostkę werbalną, której członem jest ciąg łącznie. Lista wyróżnionych w ten sposób hipotetycznych jednostek języka może być podstawą dalszych analiz semantycznych.
\end{abstract}

Słow a klucze: leksykalna jednostka języka; składnia; przysłówek kolektywny; przyimek wtórny

Punktem wyjścia do rozważań zawartych w tym artykule była analiza wyrażenia łącznie pod kątem jego przynależności do grupy tzw. przysłówków kolektywnych ${ }^{1}$, czyli - w dużym uproszczeniu - przysłówków wyrażających współwystępowanie czy współuczestniczenie elementów jakiegoś zbioru w pewnym stanie rzeczy. Mowa tu o takich wyrażeniach, jak: razem, wspólnie, do spółki, na spółkę, pospołu itp. Celem tego artykułu jest próba wyróżnienia typów kontekstów, w jakich występuje ciąg łącznie i zaproponowanie

1 Zagadnienie przysłówków kolektywnych podejmuję także w: Rosalska 2013 i 2014 , wcześniej na ich temat pisał także Maciej Grochowski (1999, 2001). 
na tej podstawie listy jednostek leksykalnych ${ }^{2}$, które może on reprezentować lub których może być członem. Postaram się wskazać pewne zależności semantyczne i składniowe różniące poszczególne typy wystąpień interesującego mnie wyrażenia, które mogą być kluczowe dla wyodrębnienia hipotetycznych jednostek języka, nie będę natomiast w tym miejscu podejmować próby eksplikacji znaczenia żadnej z nich. Każdemu analizowanemu przeze mnie typowi kontekstów poświęcam osobny, wyodrębniony śródtytułem fragment artykułu - wyjątek stanowi jego pierwsza część, w której zestawiam dwa rodzaje kontekstów rejestrujących ciąg tącznie pozostających w moim przekonaniu w regularnej zależności składniowo-semantycznej.

\section{Typ I i Ia}

Wyrażenia takie jak razem, wspólnie, do spótki, na spółkę, pospołu, a także szczególnie interesujące mnie w tym miejscu tącznie mogą występować w zdaniach jako osobne jednoelementowe jednostki języka (przysłówki), ale bywają również interpretowane jako człony przyimków wtórnych, gdy prawostronnie przyłączają segment $z$ (ze). Zdania z przysłówkami kolektywnymi dają się reorganizować $\mathrm{w}$ zdania $\mathrm{z}$ tak interpretowanymi wyrażeniami w sposób regularny, a regularność ta przejawia się na dwóch płaszczyznach - po pierwsze, każdy z przysłówków kolektywnych podlega temu przekształceniu $^{3}$, po drugie, przekształcenie to, niezależnie od tego, którego przysłów-

${ }^{2}$ Koncepcję jednostki leksykalnej, która powstała na bazie teorii jednostki języka Andrzeja Bogusławskiego (por. np. Bogusławski 1976, 1987), przyjmuję za Grochowskim (1982: 28). Terminów jednostka leksykalna i jednostka języka używam wymiennie, ponieważ różnice $\mathrm{w}$ ich rozumieniu wynikające $\mathrm{z}$ szerszego odniesienia drugiego $\mathrm{z}$ nich nie dotyczą bezpośrednio obiektów mojego opisu.

3 Zależność tę można zauważyć również w tekstach dawnych dla przysłówków, które już wyszły z użycia, jak np. wespołek i wespołek z czy naspół i naspół z, por. np. Postilla domowa: to yest: Kazania na ewangelie niedzielne y przednieysze święta tak yako ye sam Marcin Luther kazat, polnie spisat y wespołek zebrat (...), a z niemieckiego yęzyka na polski pilnie y wiernie też przełożone (Jan Daubman, 1574) i Wystuchawszy takiego poselstwa od nich, wpadt byt w wielka trwogę i myślac na obie stronie wespołek z niektórymi władykami, żadnego responsu stusznego niedał (...) (Dzieje kościołów wyznania helweckiego w Litwie: Przez Józefa Lukaszewicza, t. 1, 1842). Ta sama zasada dotyczy stosunkowo nowego w polszczyźnie przysłówka kolektywnego wespół $w$ zespół i utworzonego od niego wyrażenia wespół w zespół z, por. np. Będa także wespół w zespót walczyć z Radą Europejska o pobłażliwe potraktowanie kolejnej dziury w budżetach obu 
ka kolektywnego dotyczy, wnosi do zdania taki sam ładunek semantyczny - hierarchizuje elementy zbioru ${ }^{4}$, ale nie ma żadnego wpływu na ograniczenia semantyczne nakładane na orzeczenie i na frazy nominalne nazywające te elementy, por.:

(1) Jan i Maria biegna razem.

(1a) Jan biegnie razem z Maria.

(2) *Jan i Maria biegna tacznie.

(2a) *Jan biegnie tacznie z Maria.

Niemożliwość przekształcenia w taki sposób zdania z wyrażeniem identycznym z którymś z przysłówków kolektywnych każe przypuszczać, że wyrażenie to przysłówkiem kolektywnym nie jest, por.:

(3) Dwa i trzy to razem pięć.

(3a) *Dwa to pięć razem z trzy.

(3b) *Dwa razem z trzy to pięć.

Poprawne zdania, które rejestrują wystąpienie ciągu tącznie i które podlegają takiemu przekształceniu, w NKJP są stosunkowo rzadkie. W przeciwieństwie do pozostałych przysłówków kolektywnych normalnie użyty przysłówek łącznie nie może odnosić się do elementów zbioru będących jednocześnie wykonawcami czynności wskazanej za pomocą głównego predykatu zdaniowego (stąd dewiacyjność zdań (2) i (2a)). W bardzo rzadkich przypadkach może on odnosić się do obiektów materialnych, zwykle jednak jest używany w kontekście czynności opierających się na pewnych procesach myślowych wykonywanych na zbiorach obiektów niematerialnych, por.:

państw. (NKJP) oraz Tu i ówdzie można ustyszeć, że rekrutację do Auchanu prowadzić będzie Elżbieta Zapendowska, wespót w zespót z Kuba Wojewódzkim i Marcinem Prokopem. (NKJP).

${ }^{4}$ Hierarchizacja elementów zbioru realizuje się przede wszystkim w strukturze tematyczno-rematycznej wypowiedzenia. Przy naturalnej dla języka polskiego finalnej pozycji rematu w wypowiedzeniu (1a) do rematu włączony jest jeden z elementów zbioru, zatem jego uczestnictwo w czynności wskazanej za pomocą głównego predykatu zdaniowego podlega negacji. 
(4) *Jan położyt te książki łącznie.

(5) *Książki leża na półce łacznie.

(6) Tych preparatów nie należy zażywać tacznie.

(6a) Tego preparatu nie należy zażywać łacznie z tym.

(7) Punkt A i punkt B omawiać będziemy tacznie.

(7a) Punkt A będziemy omawiać łacznie z punktem B.

\section{Typ II}

Drugi z omawianych typów wystąpień dotyczy ciągu łącznie z. Co ciekawe, w zdecydowanej większości zdań rejestrowanych w NKJP ciąg tącznie z nie jest wcale wykładnikiem regularnego przekształcenia opisanego powyżej. Jak zauważa Maciej Grochowski (2001: 164), ciąg ten, podobnie jak wyrażenie razem $z$, może wyrażać nie tylko relację współwystępowania czy towarzyszenia, ale także relację inkluzji zbiorów, por.:

(8) Oni wszyscy, łacznie z władzami samorzadowymi, nas zlekceważyli.

(9) Nieczynne będa poradnie przyszpitalne tacznie z rejestracja - powiedziała nam wczoraj dr Joanna Gortat-Kobiór, p.o. zastępcy dyrektora szpitala do spraw lecznictwa.

(10) Kupiliśmy wszystkie pakiety, tacznie z prawem do transmisji w internecie i za pomoca telefonii komórkowej.

Jak zostało wcześniej zaznaczone, na podstawie zdań korpusowych można wnioskować, że łączliwość przysłówka łącznie w konstrukcjach podlegających wspomnianemu przekształceniu jest bardzo ograniczona. Zupełnie inaczej natomiast wygląda okurencja wyrażenia łącznie $z$ występującego w zdaniach, w których komunikuje ono relację inkluzji zbiorów - w takich kontekstach jego łączliwość jest znacznie szersza niż łączliwość przysłówka kolektywnego, por. (8) i (9) oraz:

(8a) *Oni (wszyscy) tacznie nas zlekceważyli.

(9a) *Nieczynne będa tacznie poradnie szpitalne i rejestracja.

Ta asymetria może być spowodowana kontaminacją znaczeń wyrażenia łącznie $z$ i podobnie do niego brzmiącego wtacznie $z$. Drugie $\mathrm{z}$ tych wyrażeń jest 
semantycznie wyspecjalizowane wyłącznie w komunikowaniu relacji zawierania się zbiorów i od łącznie $z$ różni się m.in. nieustabilizowanym szykiem ${ }^{5}$, por.:

(11) Na wycieczkę pojechali wszyscy włacznie z dziećmi.

(11a) Na wycieczke pojechali wszyscy łacznie z dziećmi.

(11b) Na wycieczkę pojechali wszyscy z dziećmi włacznie.

(11c) *Na wycieczkę pojechali wszyscy z dziećmi łacznie.

Poprawność zdania (11a) wskazuje, że opisywane w tym miejscu łącznie $z$ różni się od tego, które wywodzi się w sposób regularny od przysłówka kolektywnego, gdyż może odnosić się do zbiorowego agensa.

\section{Typ III}

Po wpisaniu w wyszukiwarkę NKJP ciągu łącznie korpus zwraca ogromną liczbę kontekstów, w których słowo to występuje w towarzystwie określeń liczbowych albo ilościowych. Wydaje się, że w NKJP tego typu zdań rejestrujących formę łacznie jest zdecydowanie więcej niż zdań, w których takich informacji nie ma, por.:

(12) Załoga zrzuciła łącznie 17 ciężkich bomb o masie jednego i dwóch pudów.

(13) Pracę ma tam stracić łącznie 21 osób, głównie pań.

Wiele wskazuje na to, że wyrażenie to w tego typu kontekstach w ogóle nie należy do poziomu przedmiotowego języka. Nie określa ono stanu rzeczy

5 Przez leksykografów ciągi łącznie z, włącznie i włącznie z występujące w kontekstach takich jak (11)-(11b) traktowane są bardzo różnie. Dla przykładu ISJP opisuje takie wystąpienia ciągów łącznie z i włącznie z jako zwykłe połączenia przysłówka z przyimkiem, jednak już w wystąpieniach ciągu włącznie bez sąsiedztwa $z$ każe widzieć partykułę. W SWJP problem istnienia form włącznie z i tącznie z został przemilczany - ciąg łącznie (mimo tego, że jeden z użytych przykładów użycia rejestruje jego współwystępowanie $\mathrm{z}$ formą $z$ ) został tu opisany jako przysłówek, natomiast włacznie jako operator metatekstowy. Inaczej podeszli do problemu opisu tych form autorzy haseł w WSJP; tu oprócz przyimka łącznie $z$ wyróżniono także dwa przyimki oparte na ciągu włącznie włącznie z oraz do _włącznie. 
komunikowanego za pomocą głównego predykatu zdaniowego, ale referuje pewną operację mentalną dokonaną przez nadawcę i niemającą bezpośredniego związku z treścią samego czasownika konstytuującego zdanie. Widać to wyraźnie w zdaniach takich jak poniższe, por.:

(14) Odwiedziło nas dwudziestu gości.

(14a) Odwiedziło nas tącznie dwudziestu gości.

Ponadto wyraz ten w omawianym w tym miejscu typie kontekstów nie podlega negacji, co do pewnego stopnia potwierdza brak możliwości ${ }^{6}$ umieszczenia go w zdaniu na pozycji finalnej, w języku polskim typowej dla rematu, por.:

(14b) *Odwiedziło nas dwudziestu gości łącznie.

W zdaniu (14a) wraz z ciągiem łącznie nie pojawia się żadna dodatkowa informacja o czynności wykonanej przez gości, nie dowiadujemy się z niego niczego nowego o sposobie jej wykonania ani o samych gościach. Obecność tego wyrażenia mówi nam natomiast coś o tym, jak nadawca postrzega wyrażony w zdaniu zbiór. Komunikuje ono dwustopniowy proces myślowy, na który składa się po pierwsze rozbicie zbioru, po drugie ponowne jego „poskładanie” w całość. Ze zdania (14a) można wyczytać, że jego nadawca uporządkował mentalnie i przeliczył zbiór gości; taka operacja mogła być konieczna z powodu wystąpienia jakiegoś czynnika, który sprawił, że ustalenie przynależności do zbioru jego poszczególnych elementów wymagała od nadawcy przeanalizowania sytuacji (np. goście nie pojawili się w odwiedzanym miejscu równocześnie lub ktoś z gości, w przeciwieństwie do całej reszty, przyszedł tylko na krótką chwilę).

Nie chcę w tym miejscu rozstrzygać, do jakiej klasy gramatycznej należy wyrażenie tacznie w kontekstach takich jak (14a). Na podstawie bardzo

${ }^{6}$ Wyrażenie łącznie na pozycji finalnej w zdaniach takich jak (14b) da się wybronić jedynie jako dopowiedzenie niewyrażonej wcześniej treści, swego rodzaju korekta tego, co się właśnie powiedziało. W tego typu zdaniach byłabym skłonna przed takim wyrażeniem postawić przecinek, ponieważ $\mathrm{w}$ tym miejscu musi nastąpić cezura w prozodii zdania. Z analogiczną sytuacją mielibyśmy do czynienia w zdaniu: Odwiedziło nas $d w u$ dziestu gości, około. 
wstępnej i pobieżnej analizy można wnioskować, że jednostka ta realizuje cechy operatora metapredykatywnego $\mathrm{w}$ takim rozumieniu, jakie zostało przyjęte w Słowniku gniazdowym partykuł polskich, por.:

Operator metapredykatywny to operator otwierający jedną pozycję nacechowaną semantycznie (tj. wyróżniającą się inwariantem znaczeniowym), dla wyrażeń zróżnicowanych formalnie, niewchodzący na pozycje otwierane przez jednostki innych klas (z wyjątkiem partykuł). (Grochowski, Kisiel, Żabowska 2014: 27)

Natomiast ze zdefiniowanych podklas tej klasy wyrażeń najbliżej jej do operatorów aproksymacji ${ }^{7}$, ,otwierających pozycję dla wyrażeń charakteryzujących daną wielkość pod względem ilościowym sensu largo, a więc z punktu widzenia liczby, miary i ilości w ścisłym sensie" (Grochowski, Kisiel, Żabowska 2014: 27). Niestety w słowniku tym nie zostało zarejestrowane hasło łącznie, jest w nim natomiast zaklasyfikowana jako przysłówek jednostka $w$ sumie ilustrowana zdaniem, w którym bez większego uszczerbku semantycznego można by dokonać substytucji tych wyrażeń, por.:

(15) Jedza domowe kanapki do barowej herbaty, czyli w sumie sześć złotych bez jednozłotowego napiwku.

(15a) Jedza domowe kanapki do barowej herbaty, czyli łącznie sześć złotych bez jednozłotowego napiwku.

W WSJP zarówno $w$ sumie, jak i razem, które występują w analogicznych kontekstach, zostały włączone do klasy operatorów metapredykatywnych. Wyrażenie łącznie zostało natomiast opisane tylko jako przysłówek. Należy jednak zaznaczyć, że żaden z cytatów nie rejestruje omawianego użycia tego wyrażenia, a jedyną wskazaną w tym słowniku relacją semantyczną dla łącznie jest jego synonimia względem przysłówka razem.

7 Jak zaznacza Grochowski, lista podklas operatorów metapredykatywnych nie jest zamknięta. 


\section{Typ IV}

Problem jest tym bardziej złożony, że podobnie do łącznie w takich kontekstach jak (14a) działa inkluzywne łącznie z. Podobieństwo polega na tym, że wyrażenia te nie odnoszą się do sensu głównego predykatu zdaniowego, ale zdają sprawę z operacji mentalnej mówiącego, który komunikuje coś, odnosząc się do pewnej wartości liczbowej lub ilościowej, por.:

(16) Do 2004 r. państwo wypłaci z tytułu rekompensat łacznie z odsetkami około 13 miliardów złotych blisko 4 milionom osób.

(17) Na terenie gminy mamy ponad 1500 gospodarstw, tacznie z tymi na terenach rekreacyjnych.

Jeżeli wyrażenie łącznie z zarówno w zdaniu (18), jak i w zdaniu (19) komunikuje relację zawierania się zbiorów ${ }^{8}$, to można podejrzewać, że konteksty typu II i IV rejestrują tę samą jednostkę leksykalną, por.:

(18) Przyszło dwudziestu gości łącznie z ciotką.

(19) Zjadtam całe jabłko łacznie z ogonkiem.

Na rzecz takiej interpretacji przemawia fakt, że łacznie z ze zdania (19) również można podejrzewać o działanie na poziomie nieprzedmiotowym języka. Rzecz nie jest jednak oczywista, bo nie jest łatwo jednoznacznie stwierdzić, czy w zdaniu tym fraza tacznie z ogonkiem dodana jest po to, żeby powiedzieć coś o sposobie zjedzenia jabłka, czy po to, żeby wyrazić wiedzę nadawcy o tym, że zjedzenie przez niego ogonka jest czymś nieoczywistym (tak samo jak nieoczywiste jest zaliczenie do zbioru gości ciotki ze zdania (18)). Jednak na poziomie składniowym wystąpienia takie jak (18) i (19) znacząco różnią się od siebie, co uwidacznia się po zmianie ich szyku, por.:

${ }^{8}$ Odwołując się do pojęcia 'zbioru', dokonuję tu pewnego uproszczenia. W rozumieniu teorii mnogości każdy byt, którego części da się wyodrębnić, stanowi zbiór kolektywny. Do takiego zbioru należą nie tylko wyodrębnione części, ale również części tych części. W języku naturalnym zbiorem nie nazwie się obiektu, który jest postrzegany jako byt jednostkowy, z jakim mamy do czynienia np. w zdaniu (19). 
(18a) Lacznie z ciotka przyszło dwudziestu gości.

(19a) *Lacznie z ogonkiem zjadłam cate jabtko.

Dewiacyjne są również zdania, w których wyrażenia łącznie z występującego w kontekstach typu II użyje się na pozycji inicjalnej w odniesieniu do elementów, które nie pozostają ze sobą w relacji całość ${ }^{9}$ - część, jak np. w zdaniu (19a); o ich nieakceptowalności nie decyduje zatem charakter tych obiektów, por.:

(20) Przyszli wszyscy czlonkowie rodziny tacznie z ciotka.

(20a) *Lacznie z ciotka przyszli wszyscy członkowie rodziny.

W przypadku kontekstów typu III i IV interesujący mnie element (tącznie i łącznie z) mówi coś o procesie mentalnym nadawcy. Trudno bez głębszej analizy semantycznej wskazać konkretne komponenty znaczeniowe tych wyrażeń, jednak można przyjąć, że w obu typach zdań nadawca za pomocą tego elementu komunikuje, że przynależność do zbioru, o którym coś orzeka, pewnej jego części nie jest dla niego oczywista (istnieje jakiś powód, dla którego można by jej nie brać pod uwagę przy przeliczaniu jego elementów). W zdaniach takich jak (18) ta część jest wyrażana powierzchniowo, natomiast w kontekstach typu III - nie, por.:

(21) Przyszło tacznie dwudziestu gości.

Jednak nawet przy założeniu, że ogólny sens, jaki wnoszą te wyrażenia do zdań, jest bardzo podobny, nie mamy tym razem do czynienia z regularnym przekształceniem (jak w kontekstach typu I i Ia). Relację analogiczną do tej między tacznie i łącznie z ze zdań (18) i (21) może oddać jedynie para razem i razem $z^{10}$, por::

9 Mam tu na myśli byty jednostkowe, niebędące zbiorami w takim rozumieniu, jakie przyjmuje się w języku naturalnym. Wszyscy członkowie rodziny ze zdań (20) i (20a) również stanowią swego rodzaju całość, ale jest to całość innego rodzaju niż np. jabłko ze zdania (19) - konstytuują ją wszystkie możliwe elementy wyznaczonego zbioru.

10 Przykłady (22) i (22a) można zinterpretować na dwa sposoby - również jako zdania z przysłówkiem kolektywnym. 
(22) Przyszło razem dwudziestu gości.

(22a) Razem z ciotka przyszło dwudziestu gości.

Te dwie pary wyrażeń tworzą klasę zamkniętą - podobieństwa semantyczne pomiędzy łacznie i łacznie $z$ w kontekstach typu III i IV nie są zatem wystarczającym argumentem na rzecz tego, że są to dwie różne realizacje tej samej jednostki leksykalnej.

\section{Typ V}

Stosunkowo częstym typem kontekstów w NJKP są również zdania, w których mowa o pisowni wyrazów. W ISJP takie użycia zostały potraktowane przez leksykografa jako realizacje osobnej jednostki leksykalnej, por.:

Jeśli jakieś wyrazy lub cząstki wyrazowe pisze się lącznie, to pisze się je jako jedno słowo. Łącznie piszemy cząstkę „by” z osobowymi formami czasowników, np. „krzyczałbym”.

Intuicje autora powyższej definicji wydają się słuszne - łącznie w tym typie kontekstów nie jest zwykłą realizacją przysłówka kolektywnego. Dowodem na to jest fakt, że omawiany typ zdań nie podlega opisywanemu wcześniej przekształceniu składniowo-semantycznemu charakterystycznemu dla zdań z przysłówkami kolektywnymi, por.:

(23) ?,,Nie” i rzeczowniki piszemy tącznie.

(23a) „Nie” piszemy łacznie z rzeczownikami.

Akceptowalność zdania (23), w którym przez analogię do zdania (1) wyrażenia nazywające elementy zbioru połączone zostały spójnikiem, jest dyskusyjna. Zdanie (23a) nie jest dewiacyjne, ale z pewnością nie rejestruje tego regularnego przekształcenia. Segment łącznie z nie stanowi w tym kontekście całości syntaktycznej, a zestawienie tych dwóch słów jest jedynie konsekwencją przyjętego szyku. Tę samą treść można oddać przy zastosowaniu innego porządku linearnego zdania, por.:

(23b) „Nie” z rzeczownikami piszemy łacznie. 
Podobne zdania możemy znaleźć wśród tych, które bez wątpienia rejestrują przysłówki kolektywne, por::

(24) Gazety z książkami leżały na stole razem.

(25) ?Punkt A z punktem B omawiać będziemy tacznie.

Poprawność zdań takich jak (25) jest wątpliwa, jednak nawet przy założeniu, że nie są one dewiacyjne, nie mogą być argumentem na rzecz kolektywności wyrażenia łącznie w takich kontekstach jak (23b). Zdania (24) i (25) mają analogiczną budowę składniową, tego samego nie można jednak powiedzieć o zdaniach (7a) i (23a). Różnica ta uwidacznia się w strukturze tematyczno-rematycznej wypowiedzeń i w możliwości zanegowania całej frazy otwieranej przez interesujące mnie wyrażenie, por::

(26) Nieprawda, że punkt A omawiać będziemy tacznie z punktem B (punkt A omówimy osobno).

(27) *Nieprawda, że „nie” piszemy lącznie z czasownikami.

Obecność przyimka $z$ w zdaniu (23a) nie jest również semantycznie determinowana przez wyrażenie łącznie. Równie dobrze może się on pojawić w zdaniu z przysłówkiem o przeciwstawnym znaczeniu, także w różnych konfiguracjach linearnych, por.:

(28) „Nie” z czasownikami piszemy rozłacznie.

(28a) „Nie” piszemy rozłącznie z czasownikami.

Jeżeli zdania takie jak (23b) nie rejestrują kolektywnego użycia przysłówka łacznie, to należałoby rozważyć, czy jako jednostka języka naturalnego lub jako termin w ostatnim z opisywanych typów kontekstów nie powinno być traktowane wyrażenie pisać łącznie (oraz przez analogię wyrażenie pisać rozłacznie).

Podsumowując, można wyróżnić aż sześć typów kontekstów, w których występuje ciąg łącznie, przy czym dwa opisane przeze mnie jako pierwsze (I i Ia) byłabym skłonna interpretować raczej jako zdania rejestrujące jedną jednostkę leksykalną o kształcie tacznie oraz jej regularne przekształcenie (tacznie z), a nie jako dwa osobne leksemy. Pozostałe cztery typy mogą odpo- 
wiadać czterem różnym jednostkom języka. Konteksty opisane jako II i IV rejestrują wystąpienie dwóch hipotetycznych jednostek tącznie z, z których obie wyrażają relację inkluzji zbiorów, jednak różnią się od siebie restrykcjami dotyczącymi łączliwości semantycznej i szyku. Pod numerem III została opisana hipotetyczna jednostka leksykalna o kształcie łącznie, dająca się zaklasyfikować jako operator metapredykatywny. Ostatni typ wystąpień jest ograniczony do zdań mówiących o ortografii. Opisane typy kontekstów reprezentują następujące zdania:

Typ I: Punkt A i punkt B omawiać będziemy łącznie.

Typ Ia: Punkt A będziemy omawiać łacznie z punktem B.

Typ II: Zjadtam cate jabłko łacznie z ogonkiem.

Typ III: Przyszło łacznie dwudziestu gości.

Typ IV: Łacznie z ciotka przyszło dwudziestu gości.

Typ: V: „Nie” z rzeczownikami piszemy tacznie.

Wyodrębnienie aż pięciu hipotetycznych jednostek leksykalnych opartych na ciągu łącznie z pewnością koliduje w pewnym stopniu z zasadami redukcjonizmu. Zakładam jednak, że niniejsze opracowanie może stanowić podstawę do dalszych analiz składniowo-semantycznych opisanych w nim wyrażeń, które być może pozwolą zmniejszyć tę liczbę.

\section{Bibliografia}

BogusŁawski A., 1976, O zasadach rejestracji jednostek języka, Poradnik Języko$w y, 8$, s. 356-364.

BogusŁawski A., 1987, Obiekty leksykograficzne i jednostki języka, w: Z. Saloni (red.), Studia z polskiej leksykografii współczesnej 3, Białystok: Wydawnictwo Filii Uniwersytetu Warszawskiego, s. 13-31.

Grochowski M., 1982, Zarys leksykologii i leksykografii. Zagadnienia synchroniczne, Toruń: Wydawnictwo Naukowe Uniwersytetu Mikołaja Kopernika.

Grochowski M., 1999, O strukturze semantycznej przysłówków kolektywnych, w: J. Adamowski, S. Niebrzegowska (red.), W zwierciadle języka i kultury, Lublin: Wydawnictwo Uniwersytetu Marii Curie-Skłodowskiej, s. 47-53.

Grochowski M., 2001, Sekundäre Präpositionen mit dem Segment z als Exponent der Relation des gemeinsamen Auftretens im Polnischen, w: W. Boeder, G. Hentschel (red.), Variierende Markierung von Nominalgruppen in Sprachen unter- 
schiedlichen Typs, Oldenburg: Bibliotheks- und Informationssystem der Universität Oldenburg, s. 153-170.

ISJP: 2000, Inny stownik języka polskiego, M. Bańko (red.), Warszawa: Wydawnictwo Naukowe PWN.

RosalsKa P., 2013, Wstęp do analizy semantycznej przysłówków kolektywnych (na przykładzie razem), Linguistica Copernicana, nr 1, s. 169-185.

Rosalska P., 2014, Analiza semantyczna przysłówka solo, w: A. Moroz, P. Sobotka, M. Żabowska (red.), Maiuscula linguistica. Studia in honorem Professori Matthiae Grochowski sextuagesimo quinto dedicata, Warszawa: BEL Studio, s. 309-317.

SGPP: 2014, M. Grochowski, A. Kisiel, M. Żabowska, Stownik gniazdowy partykut polskich, Kraków: Polska Akademia Umiejętności.

SWJP: 1996, Stownik wspótczesnego języka polskiego, B. Dunaj (red.), Warszawa: Wydawnictwo Wilga.

WSJP: 2007-, Wielki słownik języka polskiego, P. Żmigrodzki (red.), Kraków, słownik online: www.wsjp.pl [dostęp: 30.04.2020].

\section{Units of language based on the string tacznie}

\section{( s u m mary)}

The article presents an analysis of the six types of contexts in the Polish language, in which there is a sequence tacznie. Its purpose was to make an attempt to isolate the units of language which this sequence may represent or which it may be a part of. Five hypothetical units of language were distinguished - two represented by the sequence tacznie, two represented by the sequence tacznie $z$, and one multi-segmental verbal unit which the sequence tacznie is a part of. The list of the hypothetical units of language that are determined in this way may constitute a basis for further semantic analyses.

Keywords: a lexical unit of language; syntax; collective adverb; secondary preposition 
